\title{
Analisis Kualitas Minyak Nilam Asal Kolaka Utara Sebagai Upaya Meningkatkan dan Mengembangkan Potensi Tanaman Nilam (Pogostemon sp.) di Sulawesi Tenggara
}

\author{
Abraham R. ${ }^{1, *}$; La Rudi $^{1}$; Arniah $^{1}$; La Ode Arham²; Muna Erna Wati ${ }^{3}$ \\ ${ }^{1}$ Jurusan Pendidikan Kimia FKIP Universitas Halu oleo, Kampus Bumi Tridharma Anduonohu, \\ Kendari \\ ${ }^{2}$ Jurusan Teknik Pertambangan Institut Teknologi Sumatra, JIn. Terusan Ryacudu, Lampung \\ Selatan. \\ ${ }^{3}$ Madrasah Aliyah Negeri Maluku Tenggara, Jln. Soekarno Hatta, Maluku Tenggara.
}

*Corresponding author: abrahamunhalu@yahoo.com

\begin{abstract}
The economic value of patchouli oil is largely determined by its quality. The research objective was to study the quality of patchouli oil in North Kolaka. Quality analysis based on physical chemical properties of patchouli oil. The quality of patchouli oil (sample la and 1b) products from the distillation industry in North Kolaka has fulfilled most of the specifications of SNI quality standards. Patchouli oil (Sample 2), obtained by processing patchouli plant samples from North Kolaka by good and correct postharvest and refining methods, the quality has met all SNI quality specifications. Patchouli oil in North Kolaka has good quality potential and can meet Indonesian patchouli oil quality specifications.
\end{abstract}

Keywords: patchouli, patchouli oil quality, North Kolaka

\begin{abstract}
Abstrak
Nilai keekonomian minyak nilam sangat ditentukan oleh kualitasnya. Penelitian ini bertujuan untuk mengetahui kulitas minyak nilam Kolaka Utara. Analisis kualitas berdasarkan Sifat Fisika-Kimia minyak nilam. Kualitas minyak nilam (sampel la dan 1b) produk industri penyulingan masyarakat Kolaka Utara telah memenuhi sebagian parameter spesifikasi standar mutu minyak nilam Indonesia (SNI). Minyak nilam (sampel 2) kualitasnya telah memenuhi seluruh spesifikasi standar mutu SNI. Minyak sampel 2 diolah dari sampel tanaman nilam Kolaka Utara dengan cara panen dan penanganan pascapanen serta teknis penyulingan yang baik dan benar. Minyak nilam Kolaka Utara memiliki potensi kualitas yang baik dan memenuhi seluruh spesifikasi standar mutu SNI.
\end{abstract}

Kata kunci: nilam, kualitas minyak nilam, Kolaka Utara 


\section{Pendahuluan}

Nilam (Pogostemon sp.) telah dikenal di Indonesia sejak tahun 1895. Pertamakali dibawa oleh orang Belanda dan digunakan sebagai tanaman sela di perkebunan kopi di kaki Gunung Pasaman Sumatera Barat yang kemudian menyebar ke daerah Aceh [1]. Penanaman nilam juga menyebar ke daerah lain seperti pulau Jawa hingga Sulawesi dan saat ini telah di kembangkan di Sulawesi Tenggara yang dimulai dari Kabupaten Kolaka Utara.

Dari data yang ada di PEMDA Kolaka Utara, hingga pertengahan Juli 2011 telah ada 97 unit usaha penyulingan minyak nilam masyarakat di Kolaka Utara [2]. Tahun 2016 luas area perkebunan tanaman nilam di Kolaka Utara sekitar 248 hektar. Nilam dan minyak nilam merupakan komoditi perdagangan Kolaka Utara yang memiliki nilai jual yang tinggi [2]. Tahun 2016 Volume perdagangan antar Pulau untuk tumbuhan nilam mencapai 4.274 ton (Rp. 941.550.000,-) dan minyak nilam mencapai 150.094 ton (Rp. 149. 210.440.000,-) [2]. Akan tetapi, agribisnis nilam di daerah Kolaka Utara terkendala oleh harga minyak nilam yang berfluktuasi dan cendrung menurun. Fluktuasi harga minyak nilam disebabkan berbagai macam hal, antara lain beragamnya kualitas minyak nilam yang dihasilkan masyarakat.

Kualitas minyak nilam yang berlaku di Indonesia mengacu pada spesifikasi standar mutu SNI (SNI: 06-2385-2006) yang mencirikan sifat fisika dan sifat kimia dari minyak. Minyak nilam dengan kualitas mutu yang lebih baik dihargai lebih tinggi dibanding minyak nilam dengan kualitas mutu yang kurang baik [3]. Analisis GC-MS menunjukkan bahwa kandungan komponen utama pada minyak nilam dari Indonesia adalah patchouli alkohol sebesar 32,2\% [4].

Sampai saat ini belum pernah dilakukan pengkajian ilmiah terhadap kualitas minyak nilam produksi masyarakat di Sulawesi Tenggara khususnya di Kolaka Utara dalam bentuk analisis sifat fisika kimia dari minyak, sehingga tidak ada informasi yang dapat menggambarkan kualitas sebenarnya dari minyak nilam tersebut yang merupakan modal dasar untuk acuan penentuan harga ekonomi minyak nilam di pasar global.

Sebagai upaya meningkatkan dan mengembangkan prospek usaha tanaman nilam di Kolaka Utara, maka pada kegiatan penelitian ini telah dilakukan pengkajian kualitas minyak nilam dari Kolaka Utara melalui analisis sifat-sifat fisika kimia minyak, baik minyak nilam olahan industri 
penyulingan masyarakat Kolaka Utara maupun minyak nilam yang diolah dari sampel tanaman nilam asal Kolaka Utara guna mengetahui potensi kualitas minyak nilam dari Kolaka Utara.

\section{Metode Penelitian}

\section{a. Alat dan Bahan}

Peralatan yang digunakan adalah karton putih, berbagai alat-alat gelas, buret, neraca analitik, penangas air, seperangkat alat refluks, piknometer, termometer, refraktometer, dan seperangkat alat kromatografi gas-spektrometri massa (GCMS) merek Shimadzu class QP 5000.

Bahan kimia yang digunakan adalah etanol, dietil eter, kalium hidroksida, asam klorida, dan indi kator fenolftalein dengan kualitas pro analisis dari E. Merck serta gas helium dengan kualitas ultra high purity untuk gas pembawa (carrier gas).

\section{b. Observasi pengelolaan tanaman nilam dan minyak nilam di Kolaka Utara}

Kegiatan ditujukan untuk memperoleh gambaran teknis pemanenan dan penanganan pascapanen tanaman nilam yang dilakukan petani di Kolaka Utara serta teknis penyulingan dan penyimpanan minyak nilam pada industri penyulingan minyak nilam masyarakat di Kolaka Utara

\section{c. Pengambilan Sampel}

- Sampel minyak nilam dari industri penyulingan masyarakat di Kolaka Utara

Pengambilan sampel minyak nilam hasil industri penyulingan minyak nilam masyarakat di Kolaka Utara dilakukan dengan mempertimbangkan bahan dasar ketel penyulingan yang digunakan masyarakat yaitu dari bahan plat besi dan plat stainless steel. Minyak nilam dengan kode sampel 1a diambil dari industri penyulingan masyarakat yang bahan dasar ketelnya plat besi. Minyak nilam dengan kode sampel $1 \mathrm{~b}$ diambil dari industri penyulingan masyarakat yang bahan dasar ketelnya plat stainless steel.

- Sampel tanaman nilam dari lahan petani di Kolaka Utara.

Sampel tanaman nilam dipanen dari lahan petani di Kolaka Utara pada pagi hari hingga menjelang siang, tanaman nilam dipilih yang memiliki potensi kandungan minyak atsiri terbesar yakni daunnya masih hijau segar dengan usia panen sekitar 3 bulan.

\section{d. Pengelolaan sampel tanaman nilam.}

- Penanganan pascapanen

Sampel tanaman nilam yang telah dipanen dari lahan petani di Kolaka Utara segera dikeringkan dengan dua tahapan yaitu dijemur dengan sinar matahari langsung selama 6 jam dilanjutkan dengan dikering 
anginkan selama 3 hari. Daun dan batang tanaman nilam yang telah kering selanjutnya dirajang kemudian ditimbang dan siap disuling minyaknya.

- Penyulingan minyak nilam

Penyulingan minyak dari sampel tanaman nilam dilakukan dengan metode destilasi uap menggunakan ketel dan kondensor yang berbahan plat stainless steel selama 8 jam, minyak nilam yang diperoleh diberi kode sampel 2.

\section{e. Analisis kualitas minyak nilam.}

Ketiga sampel (1a, 1b dan 2) minyak nilam dianalisis kualitasnya berdasarkan parameter sifat fisika kimia minyak meliputi warna minyak, bobot jenis, indeks bias, kelarutan minyak dalam etanol, bilangan ester, bilangan asam minyak, dan kadar Patchouli alkohol minyak. Hasil analisis sifat fisika kimia ketiga sampel minyak nilam dibandingkan dengan spesifikasi standar mutu minyak nilam Indonesia (SNI).

\section{f. Prosedur analisis sifat fisika kimia minyak nilam.}

- Penentuan warna

Sampel minyak dipipet $10 \mathrm{~mL}$ kedalam tabung reaksi, tabung reaksi tersebut disandarkan pada kertas/karton putih dan diamati secara langsung pada jarak $30 \mathrm{~cm}$. Hasil dinyatakan sesuai dengan warna sampel minyak yang diamati.
- Penentuan Bobot Jenis

Piknometer bersih dan kering ditimbang $(\mathrm{m})$. Piknometer diisi air suling pada suhu $25^{\circ} \mathrm{C} \pm 0,2^{\circ} \mathrm{C}$, tutupnya disisipkan dan ditimbang $\left(\mathrm{m}_{1}\right)$.

Piknometer dikosongkan, dicuci dengan etanol dan dietil eter, dikeringkan. Piknometer diisi sampel minyak pada suhu $25^{\circ} \mathrm{C} \pm 0,2^{0} \mathrm{C}$, tutupnya disisipkan dan ditimbang $\left(\mathrm{m}_{2}\right)$.

Bobot jenis minyak dihitung dengan rumus:

$$
\text { Bobot jenis }=d_{25}^{25}=\frac{m_{2}-m}{m_{1}-m}
$$

- Penentuan Indeks Bias

Pemeriksaan indeks bias minyak nilam dilakukan pada suhu $25^{\circ} \mathrm{C}$ dengan menggunakan alat refraktometer.

Indeks bias dihitung dengan rumus:

$$
\text { Indeks bias }=\mathrm{n}_{\mathrm{D}}^{\mathrm{t}}=\mathrm{n}_{\mathrm{D}}^{\mathrm{t} 1}+0,0004(\mathrm{t} 1-\mathrm{t})
$$

$$
\text { dimana: } \begin{aligned}
\mathrm{n}_{\mathrm{D}}^{\mathrm{t} 1} & =\text { pembacaan yang dilakukan pada } \\
& \text { suhu pengerjaan } \mathrm{t} 1 \\
\mathrm{t} 1 & \text { suhu pengerjaan }\left(25^{\circ} \mathrm{C}\right) \\
\mathrm{t} \quad & \text { suhu pada } 20^{\circ} \mathrm{C} \\
0,0004= & \text { faktor koreksi indeks bias untuk } \\
& \text { minyak nilam }
\end{aligned}
$$

- Penentuan Kelarutan dalam Etanol

Sebanyak $1 \mathrm{~mL}$ sampel minyak didalam gelas ukur $10 \mathrm{~mL}$, ditambahkan etanol $90 \%$ setetes demi setetes pada suhu 20 ${ }^{0} \mathrm{C}$, dan setiap tetes penambahan dikocok sampai diperoleh suatu larutan yang sebening 
mungkin. Bila larutan tidak bening, bandingkan kekeruhan yang terjadi dengan kekeruhan larutan pembanding.

- Penentuan Bilangan Ester Pengujian Blanko

Dalam labu penyabunan dimasukkan batu didih, ditambahkan $5 \mathrm{~mL}$ etanol dan 25 $\mathrm{mL}$ larutan $\mathrm{KOH} 0,5$ N. Dengan hati-hati refluks selama 1 (satu) jam menggunakan penangas air, kemudian diamkan hingga dingin. Kondensor refluks dilepaskan dan ditambahkan 5 tetes larutan fenolftalein kemudian dinetralkan dengan $\mathrm{HCl} 0,5 \mathrm{~N}$

\section{Pengujian Sampel}

Ditimbang $4 \mathrm{~g} \pm 0,05 \mathrm{~g}$ sampel dalam labu penyabunan, selanjutnya kondisi dan perlakuannya sama seperti pada penentuan blanko

$$
\text { Bilangan ester (E) dihitung dengan }
$$
rumus :

$$
E=\frac{56,1\left(v_{1}-v_{0}\right) N}{m}
$$

$\begin{aligned} \text { Dimana : 56,1 } & =\text { Bobot setara } \mathrm{KOH} \\ \mathrm{V} 1 & =\text { Volume } \mathrm{HCl} \text { yang digunakan } \\ & \text { dalam penentuan blanko }(\mathrm{mL}) \\ \mathrm{V} 0 & =\text { Volume } \mathrm{HCl} \text { yang digunakan } \\ & \text { dalam penenentuan sampel }(\mathrm{mL}) \\ \mathrm{m} & =\text { massa sampel yang diuji }(\mathrm{g}) \\ \mathrm{N} & =\text { Normalitas } \mathrm{HCl}\end{aligned}$

- Penentuan Bilangan Asam
Ditimbang $4 \mathrm{~g} \pm$ 0,05 g sampel minyak, dilarutkan dalam $5 \mathrm{~mL}$ etanol netral pada labu saponifikasi alas bulat, ditambahkan 5 tetes larutan indikator fenolftalein dan dititrasi dengan $\mathrm{KOH} 0,1 \mathrm{~N}$ sampai warna merah muda.

Bilangan asam dihitung dengan rumus :

$$
\begin{array}{cl}
\multicolumn{3}{c}{\text { Bilangan asam }=\frac{56,1 \times V \times \mathrm{N}}{\mathrm{m}}} \\
\text { Dengan: } 56,1 \quad=\text { bobot setara KOH } \\
\mathrm{V} \quad=\operatorname{volume} \text { larutan KOH yang } \\
& \text { diperlukan }(\mathrm{mL}) \\
\mathrm{N} & =\text { normalitas larutan KOH }(\mathrm{N}) \\
\mathrm{m} & =\text { massa sampel minyak }
\end{array}
$$

- Penentuan Kadar Patchouli Alkohol Kadar patchouli alkohol sampel minyak ditentukan berdasarkan analisis luas relatif kromatogram gas yang diukur dengan instrumen GC-MS.

\section{Hasil dan Pembahasan}

Industri penyulingan minyak nilam masyarakat di Kolaka Utara seluruhnya menggunakan cara destilasi uap. Destilasi uap adalah metode ekstraksi terbaik untuk minyak nilam [5]. Bahan dasar ketel penyulingan masyarakat di Kolaka Utara sebagian besar (lebih dari 80\%) terbuat dari plat besi dan sisanya terbuat dari plat stainless steel. Bahan dasar kondensor pada industri penyulingan masyarakat seluruhnya terbuat dari stainless steel, termasuk yang bahan ketelnya dari plat besi. Bahan stainless 
steel adalah bahan yang ideal digunakan dalam penyulingan minyak atsiri karena tidak bereaksi dengan minyak sehingga minyak atsiri yang dihasilkan dapat terjaga kemurniannya [6].

Penyulingan minyak nilam dilakukan hingga destilat tidak lagi mengandung minyak dengan waktu sekitar 10-14 jam. Kapasitas ketel penyulingan minyak nilam masyarakat untuk sekali destilasi sekitar 450-
$500 \mathrm{Kg}$ terna nilam dengan rendemen minyak sekitar $1,8-2 \%$.

Hasil analisis sifat fisika kimia minyak nilam yang diperoleh dari industri penyulingan masyarakat di Kolaka Utara (sampel 1a dan sampel 1b) serta minyak nilam sampel 2 yang diperoleh dari mengolah sampel tanaman nilam masyarakat Kolaka Utara (dengan rendemen minyak 2,01\%), ditampilkan pada Tabel 1.

\section{Tabel 1. Kualitas Minyak Nilam Kolaka Utara}

\begin{tabular}{|c|c|c|c|c|c|}
\hline \multirow[b]{2}{*}{ No. } & \multirow[b]{2}{*}{$\begin{array}{c}\text { Parameter } \\
\text { Pengamatan }\end{array}$} & \multicolumn{2}{|c|}{$\begin{array}{c}\text { Minyak nilam produk industri } \\
\text { masyarakat (1) }\end{array}$} & \multirow{2}{*}{$\begin{array}{c}\text { Minyak nilam } \\
\text { yang diolah dari } \\
\text { sampel tanaman } \\
\text { nilam } \\
\text { (sampel 2) }\end{array}$} & \multirow{2}{*}{$\begin{array}{c}\text { Spesifikasi } \\
\text { standar mutu } \\
\text { minyak nilam } \\
\text { Indonesia } \\
\text { (SNI) [3] }\end{array}$} \\
\hline & & $\begin{array}{c}\text { yang disuling } \\
\text { dengan ketel } \\
\text { plat Besi } \\
\text { (sampel 1a) }\end{array}$ & $\begin{array}{c}\text { yang disuling } \\
\text { dengan ketel } \\
\text { plat Stainless } \\
\text { (sampel 1b) }\end{array}$ & & \\
\hline 1. & Warna & $\begin{array}{c}\text { Kuning } \\
\text { kecoklatan } \\
\text { (agak gelap) }\end{array}$ & $\begin{array}{c}\text { Kuning muda } \\
\text { (Jernih) }\end{array}$ & $\begin{array}{c}\text { Coklat } \\
\text { kemerahan } \\
\text { (Jernih) }\end{array}$ & $\begin{array}{c}\text { Kuning muda } \\
\text { sampai coklat } \\
\text { kemerahan }\end{array}$ \\
\hline 2. & Bobot Jenis $\left(25^{\circ} \mathrm{C}\right)$ & 0,953 & 0,951 & 0,972 & $0,950-0,975$ \\
\hline 3. & Indeks Bias $\left(\mathrm{nD}^{20}\right)$ & 1,502 & 1,512 & 1,512 & $1,507-1,515$ \\
\hline 4. & $\begin{array}{l}\text { Kelarutan dalam } \\
\text { etanol } 90 \%\end{array}$ & $\begin{array}{c}1: 1,1 \\
\text { (seterusnya } \\
\text { jernih) }\end{array}$ & $\begin{array}{c}1: 1,3 \\
\text { (seterusnya } \\
\text { jernih) }\end{array}$ & $\begin{array}{c}1: 1 \\
\text { (seterusnya } \\
\text { jernih) }\end{array}$ & $\begin{array}{l}\text { Larutan jernih } \\
\text { atau opalensi } \\
\text { ringan }(1: 10)\end{array}$ \\
\hline 5. & Bilangan Ester & 2,8 & 6,3 & 7,7 & Maksimal 20 \\
\hline 6. & Bilangan Asam & 2,5 & 12 & 4,2 & Maksimal 8 \\
\hline 7. & $\begin{array}{l}\text { Patchouli Alkohol } \\
(\%)\end{array}$ & 22,76 & 29,44 & 48,25 & Minimal 30\% \\
\hline
\end{tabular}


Teknis penyulingan mempengaruhi kualitas minyak. Pada Tabel 1. nampak bahwa minyak nilam yang disuling dengan ketel berbahan plat besi (sampel 1a) berwarna kuning kecoklatan dan nampak agak gelap. Penyulingan dengan ketel dari bahan plat besi menyebabkan zat besi pada ketel juga ikut bersama destilat dan terlarut dalam minyak sehingga warna minyak sampel 1a agak gelap dan tidak memenuhi spesifikasi standar mutu SNI. Minyak nilam (sampel 1b dan sampel 2) disuling dengan ketel berbahan plat stainless steel. Minyak sampel $1 \mathrm{~b}$ nampak jernih dengan warna kuning muda, minyak sampel 2 juga nampak jernih dengan warna coklat kemerahan. Kedua sampel (1b dan 2) minyak nilam memiliki tingkat kemurnian yang sangat baik serta memenuhi spesifikasi standar mutu SNI.

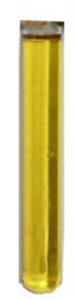

sampel 1a sampel 1b sampel 2

Gambar 1. Uji Warna tiga sampel minyak nilam Kolaka Utara

Bobot jenis ketiga sampel $(1 \mathrm{a}, 1 \mathrm{~b}, 2)$ minyak nilam telah memenuhi spesifikasi standar mutu SNI. Ketiga sampel minyak diperoleh dengan cara destilasi uap. Metode destilasi uap memungkinkan komponenkomponen terpen teroksigenasi dengan berat molekul tinggi ikut tersuling [6]. Bobot jenis sampel 2 yang lebih tinggi dibanding sampel 1a dan 1b, menunjukkan bahwa sampel 2 lebih kaya akan komponen terpen teroksigenasi dan mengarah ke mutu minyak yang lebih baik dibanding dua sampel minyak yang lain.

Indeks bias dua sampel (1b dan 2) minyak nilam memenuhi spesifikasi standar mutu SNI, kecuali sampel 1a yang tidak memenuhi SNI. Nilai indeks bias yang tinggi dapat disebabkan karena komponenkomponen terpen teroksigenasi pada sampel $1 \mathrm{~b}$ dan sampel 2 mengandung molekul berantai panjang dengan ikatan tak jenuh atau mengandung banyak gugus oksigen [7]. Indeks bias yang tinggi mengarah ke mutu minyak yang lebih baik.

Ketiga sampel (1a, 1b, 2) minyak nilam larut dengan baik dalam alkohol. Kelarutan sampel 2 dalam alkohol sedikit lebih baik dibanding sampel $1 \mathrm{a}$ dan $1 \mathrm{~b}$, hal ini menunjukkan bahwa minyak nilam sampel 2 lebih kaya akan komponen terpen teroksigenasi dengan mutu minyak yang lebih baik. Bilangan ester ketiga sampel (1a, 1b, 2) minyak nilam telah memenuhi 
spesifikasi standar mutu SNI. Bilangan ester sampel 2 juga paling tinggi diikuti sampel $1 \mathrm{~b}$. Bilangan ester yang tinggi menggambarkan bahwa minyak tidak mudah teroksidasi sehingga komposisi bau lebih sempurna dan ketahanan bau lebih lama. Bilangan ester yang terlalu tinggi (lebih dari 20) menunjukkan adanya bahan tambahan yang dicampurkan pada minyak dan merupakan indikasi pemalsuan minyak nilam [8].

Bilangan asam dua sampel (1a dan 2) minyak nilam memenuhi spesifikasi standar mutu SNI, kedua sampel minyak tersebut langsung disimpan dalam botol kaca gelap dan ditutup rapat sesaat setelah selesai proses penyulingan. Bilangan asam sampel $1 \mathrm{~b}$ sangat tinggi dan tidak memenuhi SNI. Bilangan asam yang tinggi mengindikasikan penurunan mutu minyaknya, hal tersebut dapat disebabkan karena minyak nilam sampel 1b yang diperoleh telah disimpan selama beberapa hari oleh petani penyuling di dalam jerigen plastik yang tertutup rapat. Minyak nilam sebaiknya dikemas dalam wadah yang tahan minyak seperti botol gelap atau drum yang bagian dalamnya dilapisi timah putih, galvanis atau berenamel. Lama penyimpanan serta media penyimpanan minyak sampel $1 \mathrm{~b}$ yang kurang baik yakni pada jerigen plastik, memungkinkan interaksi udara luar dengan minyak nilam. Interaksi udara dengan minyak menyebabkan perubahan komponen terpen teroksigenasi menjadi asam karboksilat melalui proses oksidasi komponen alkohol dan hidrolisis komponen ester.

Kandungan senyawa patchouli alkohol dua sampel (1a dan 1b) belum memenuhi persyaratan minimal SNI (30\%). Kandungan patchouli alkohol sampel 1a sangat rendah jauh dibawah persyaratan minimal SNI, hal tersebut karena teknis penyulingannya yang kurang ideal dengan bahan ketel dari plat besi. Kandungan patchouli alkohol sampel $1 \mathrm{~b}$ sedikit dibawah persyaratan minimal SNI, walaupun teknis penyulingan minyak sampel 1b sudah ideal dengan ketel dari plat stainless steel akan tetapi media penyimpanan yang kurang baik menyebabkan kualitas minyaknya menurun. Teknis penyulingan yang ideal dan penyimpanan minyak yang baik menyebabkan kualitas minyak sampel 2 sangat baik dengan kandungan senyawa patchouli alkoholnya berada diatas persyaratan minimal SNI. Persentase kandungan senyawa patchouli alkohol akan mempengaruhi aroma minyak nilam dan merupakan salah satu faktor yang sangat menentukan kualitas serta nilai keekonomian minyak tersebut di pasar global. 
Kualitas Minyak nilam tidak hanya dipengaruhi oleh teknis penyulingan dan media penyimpanan minyak akan tetapi juga dipengaruhi oleh kualitas bahan baku terna nilam yang disuling. Kualitas terna nilam ditentukan oleh berbagai faktor diantaranya adalah usia panen tanaman nilam dan penanganan pascapanennya. Kualitas bahan baku terna nilam pada industri penyulingan masyarakat sangat beragam. Pada satu lokasi penanaman nampak beberapa rumpun tanaman nilam daunnya masih hijau segar sementara beberapa rumpun tanaman nilam yang lain daunya sudah mulai kecoklatan. Kandungan minyak yang tinggi terdapat pada daun yang masih berwarna hijau segar [9]. Daun yang kecoklatan merupakan indikasi usia tanaman yang sudah tua, kemampuan akar dalam menyerap air akan berkurang dan suplai air ke daun juga berkurang, sehingga stomata menutup dan laju pembentukan minyak berkurang [10].

Usia produktif tanaman nilam adalah 3 tahun dan panen pertama umumnya dilakukan petani di Kolaka Utara pada umur 4-5 bulan dan penen berikutnya pada umur 2-3 bulan. Pemanenan tanaman nilam sebaiknya pada usia 3, 6, dan 9 bulan. Tanaman nilam yang dipanen pada usia 3 bulan, mengandung minyak dan patchouli alkohol tertinggi [5]. Setelah melampaui usia produktif, tanaman nilam harus diremajakan. Pada saat tanam nilam yang lama baru berusia 1,5 tahun, petani di Kolaka Utara sudah melakukan peremajaan dengan menanam tanaman nilam yang baru berdampingan dengan tanaman nilam yang lama. Hal tersebut menyebabkan usia panen tanaman nilam dalam satu lokasi penanaman menjadi tidak seragam dan berpengaruh pada kualitas terna nilamnya.

Pemanenan terna nilam umumnya dilakukan petani mulai pagi hari hingga siang hari. Pada siang hari, sel-sel daun sedang berfotosintesis sehingga laju pembentukan minyak berkurang [9]. Panen sebaiknya pagi hari atau sore menjelang malam agar kandungan minyaknya tinggi. Batang dan daun nilam yang baru dipanen langsung dirajang, kemudian dijemur dengan matahari langsung selama 2-3 hari sehingga daun dan batang nilam dengan cepat akan mengering dan mudah hancur bila diremas. Metode yang dilakukan petani di Kolaka Utara tersebut menurunkan kualitas terna nilam karena sebagian minyak yang terkandung pada terna nilam akan menguap atau mengalami dekomposisi pada saat pengeringan dengan matahari langsung.

Untuk menghasilkan terna nilam dengan kualitas yang baik, pengeringan sebaiknya dilakukan dengan dua tahapan. 
Tahap pertama, terna nilam dijemur dengan matahari langsung selama 5-6 jam, tahap selanjutnya dikering anginkan selama 3 hari dan posisi terna harus senantiasa dibolak balik [11]. Terna nilam yang kering dengan baik akan menimbulkan aroma khas dari minyak nilam, warna daun menjadi abu-abu kecoklatan dan tidak rapuh. Perajangan dimaksudkan untuk menambah luas permukaan terna nilam dan kelenjar minyak dapat terbuka optimal sehingga mempercepat penguapan minyak saat penyulingan. Oleh karena itu pengeringan terna nilam harus lebih dulu dilakukan, setelah terna nilam kering barulah dilakukan perajangan agar penguapan dan dekomposisi minyak dapat diminimalisir sehingga kuantitas dan kualitas minyak yang terkandung pada terna nilam dapat optimal.

Kualitas minyak nilam sampel 2 yang sangat baik dan memenuhi seluruh spesifikasi standar mutu SNI juga disebabkan oleh kualitas bahan baku terna nilam yang cukup baik karena diolah dengan cara-cara panen dan penanganan pascapanen yang baik dan benar. Bahan baku terna nilam untuk minyak sampel 2 dipanen pada pagi hari hingga menjelang siang, tanaman nilam dipilih yang daunnya masih hijau segar dengan usia panen sekitar 3 bulan. Nilam yang telah dipanen segera dikeringkan dengan dua tahapan yaitu pengeringan dengan sinar matahari langsung selama 6 jam dilanjutkan dengan dikering anginkan selama 3 hari. Daun dan batang terna nilam yang telah kering berwarna abu-abu kecoklatan selanjutnya dirajang dan diperoleh bahan baku terna nilam dengan tingkat kualitas yang baik.

Dari uraian berdasarkan analisis fisika kimia tersebut menunjukkan bahwa minyak nilam dari Kolaka Utara memiliki potensi kualitas yang baik dan memenuhi seluruh spesifikasi standar mutu SNI jika dikelola dengan teknis penyulingan dan penyimpanan minyak nilam yang benar serta disuling dari bahan baku terna nilam dengan tingkat kualitas cukup baik yang diperoleh melalui cara-cara panen dan penanganan pascapanen tanaman nilam yang baik.

\section{Kesimpulan}

Kandungan senyawa patchouli alkohol minyak nilam dari industri penyulingan masyarakat Kolaka Utara belum memenuhi persentase minimal dari spesifikasi standar mutu yang dipersyaratkan SNI, baik minyak yang diolah dengan ketel berbahan plat besi (sampel 1a) maupun plat stainless steel (sampel 1b). Minyak nilam sampel 1a juga belum memenuhi spesifikasi warna dan indeks bias dari SNI, sementara minyak nilam sampel $1 \mathrm{~b}$ tidak memenuhi spesifikasi 
bilangan asam dari SNI. Dengan penanganan pascapanen yang baik, teknis penyulingan yang ideal dan penyimpanan minyak nilam yang benar, diperoleh minyak nilam Kolaka Utara (sampel 2) dengan kualitas yang sangat baik dan memenuhi seluruh spesifikasi standar mutu yang dipersyaratkan SNI.

\section{UcapanTerimakasih}

Terima kasih atas dukungan dana penelitian dari Kemenristekdikti Republik Indonesia melalui LPPM Universitas Halu Oleo Kendari.

\section{DaftarPustaka}

[1] H.M.S. Mangun, "Nilam. Hasilkan minyak berkualitas mulai dari teknik budidaya hingga proses penyulingan," Penebar Swadaya, Jakarta, 2005.

[2] BPS Kolaka Utara, "Kabupaten Kolaka Utara Dalam Angka Tahun 2017," Seksi Integrasi Pengolahan dan Diseminasi Statistik Badan Pusat Statistik Kabupaten Kolaka Utara, ISBN : 978-602-6698-001, Lasusua, Jul. 2017.

[3] SNI 06-2385-2006, "Minyak Nilam," Badan Standardisasi Nasional (BSN), http://sisni.bsn.go.id/ index.php/sni/Sni/download/7400 (Diakses tanggal 25 Juli 2014).

[4] C. M. Buré and N.M. Sellier, "Analysis of the Essential Oil of Indonesian
Patchouli (Pogostemon cablin Benth.) Using GC/MS (EI/CI),” J. Essent. Oil Res., vol. 16, pp. 17-19, Jan/Feb. 2004.

[5] N. Kongkathip, P. Sam-ang, B. Kongkathip, Y. Pankaew, M. Tanasombat, and P. Udomkusonsri, "Development of Patchouli Extraction with Quality Control and Isolation of Active Compounds with Antibacterial Activity,” Kasetsart J. (Nat. Sci.), vol. 43 (3), pp. 519-525, 2009.

[6] Abraham, "Studi sifat-sifat Fisika-Kimia Minyak Akar Wangi (Vetiveria zizanioides) Liar asal Bone," Aplikasi Sains, ISSN 1410-7538, Vol. 9 (2), pp. 90-92, Jan. 2007.

[7] Abraham, "Penelusuran Struktur Molekul Puncak-Puncak Terpen Oksigenasi Minyak Akar Wangi (Vetiver Oil) Liar Asal Bone Berdasarkan Fragmentasi Spektrometri Massa," Jurnal Kimia dan Kependidikan Kimia SAINS, ISSN : 2301-5934, Vol. 1 (1), pp. 78-92, April 2012.

[8] E. Guenther, "Minyak Atsiri Jilid 1", diterjemahkan oleh Ketaren, UI-Press., Jakarta, 1987.

[9] R. Supendy, “Analisis Ekonomi dan Manajemen Perbaikan Sistem Usahatani Nilam di Desa Kabupaten Bombana Sulawesi Tenggara (Kasus di Desa 
Abraham R., dkk. Akta Kimia Indonesia 4(2), 2019, 133-144

Babamolingku)", J. Agroland Vol. 23

(2), pp. 164 - 173, Agu. 2016.

[10]T. L. Lutony dan Y. Rahmayati, "Produksi dan Perdagangan Minyak Atsiri”, Penebar Swadaya, Jakarta, 2000.
[11]P. Barus, "Desain Alat Penyulingan Minyak Nilam untuk Meningkatkan Rendemen dan Mutu," Jurnal Penelitian Rekayasa, Vol. 1 (1), pp. 37-40, 2008. 